\title{
Molecular prevalence of Theileria infections in cattle in Yanbian, north-eastern China
}

\author{
Lijun Jia ${ }^{a, *}$, Shaowei Zhao a , Suzhu Xie, Hang Li, Hao Wang, and Shuang Zhang \\ Laboratory of Veterinary Microbiology, Department of Veterinary Medicine, Agriculture College of Yanbian University, \\ No. 977 Park Road, 133000 Yanji, PR China
}

Received 23 December 2019, Accepted 16 March 2020, Published online 30 March 2020

\begin{abstract}
Bovine Theileria are tick-borne protozoan parasites that invade bovine erythrocytes and lymphocytes. Three main bovine Theileria species have been identified in China: T. orientalis, $T$. sinensis, and T. annulata. To examine the prevalence of bovine theileriosis in Yanbian, a total of 584 bovine blood samples were collected from five localities from 2017 to 2019 and analyzed by PCR. Six pairs of oligonucleotide primers directed against the 18S rRNA gene of Theileria spp., Tams-1 gene of T. annulata, MPSP gene of T. orientalis, and T. sinensis, were used to detect these parasites. A sequence analysis of the amplified genes confirmed that the Theileria species were T. orientalis and T. sinensis, without T. annulata. The overall prevalence of Theileria in cattle was $42.81 \%$ (250/584). Out of the 584 samples, $159(27.23 \%)$ and $157(26.88 \%)$ were positive for $T$. sinensis and T. orientalis, respectively, and the mixed infection rate was $11.30 \%(66 / 584)$. The total prevalence of bovine Theileria species in Helong, Hunchun, Longjing, Yanji, and Dunhua was $66.28 \%, 49.68 \%, 23.81 \%, 28.15 \%$, and $0 \%$, respectively. These results provide epidemiological data for the prevention and control of bovine Theileria species in Yanbian, China.
\end{abstract}

Key words: Theileria orientalis, Theileria sinensis, Yanbian, Epidemiology.

Résumé - Prévalence moléculaire des infections à Theileria chez les bovins à Yanbian, dans le nord-est de la Chine. Les Theileria bovins sont des parasites protozoaires transmis par les tiques qui envahissent les érythrocytes et les lymphocytes des bovins. Trois espèces principales de Theileria de bovins ont été identifiées en Chine, T. orientalis, $T$. sinensis et $T$. annulata. Pour examiner la prévalence de la theilériose bovine à Yanbian, un total de 584 échantillons de sang bovin ont été collectés dans cinq localités de 2017 à 2019 et analysés par PCR. Six paires d'amorces oligonucléotidiques dirigées contre le gène d'ARNr $18 \mathrm{~S}$ de Theileria spp., le gène Tams-1 de T. annulata et le gène MPSP de $T$. orientalis et $T$. sinensis, ont été utilisées pour détecter ces parasites. Une analyse de séquence des gènes amplifiés a confirmé que les espèces de Theileria étaient $T$. orientalis et $T$. sinensis, sans $T$. annulata. La prévalence globale des Theileria chez les bovins était de 42,81\% (250/584). Sur les 584 échantillons, $159(27,23 \%)$ et $157(26,88 \%)$ étaient positifs pour $T$. sinensis et $T$. orientalis, respectivement, et le taux d'infection mixte était de 11,30\% (66/584). La prévalence totale des espèces bovines de Theileria à Helong, Hunchun, Longjing, Yanji et Dunhua était respectivement de 66,28\%, 49,68\%, 23,81\%, 28,15\% et $0 \%$. Ces résultats fournissent des données épidémiologiques pour la prévention et le contrôle des espèces de Theileria de bovins à Yanbian, en Chine.

\section{Introduction}

Bovine theileriosis, which primarily causes fever, anaemia, jaundice, and superficial lymph node enlargement in infected animals, is a tick-borne haemoprotozoan disease caused by parasites of the genus Theileria, which invades bovine erythrocytes and leukocytes [12]. The prevalence and active regions of vector ticks are critical components of bovine Theileria

\footnotetext{
*Corresponding author: li junjial015@sohu. com

${ }^{a}$ These authors and universities made an equal contribution to this study.
}

species epidemiology. The disease, which is difficult to completely eliminate, is associated with obvious regional and seasonal epidemics. Severe infections of cattle result in death, which causes considerable economic losses and potential threats to the cattle industry [24]. It has currently been established that the causative agents of bovine theileriosis include Theileria parva, Theileria annulata, Theileria mutans, and Theileria velifera [15]. Theileria parva and Theileria annulata cause a higher mortality rate in cattle, and represent two of the most virulent species compared with the other reported Theileria species. Theileria annulata is widely distributed throughout Europe, the Middle East, Russia, China, and Africa [22], 
Table 1. Primer sequences

\begin{tabular}{|c|c|c|c|c|c|c|}
\hline Pathogen & $\begin{array}{l}\text { Target } \\
\text { gene }\end{array}$ & Assay & $\begin{array}{l}\text { Oligonucleotide sequences } \\
\left(5^{\prime} \rightarrow 3^{\prime}\right)\end{array}$ & Product size (bp) & $\begin{array}{c}\text { Annealing } \\
\text { temperature }\left({ }^{\circ} \mathrm{C}\right)\end{array}$ & Reference \\
\hline \multirow[t]{2}{*}{ Theileria spp } & $18 \mathrm{~S}$ rRNA & PCR & $\begin{array}{l}\text { GAAACGGCTACCACATCT } \\
\text { AGTTTCCCCGTGTTGAGT }\end{array}$ & 778 & 55 & Cao et al. [4] \\
\hline & & $\mathrm{nPCR}$ & $\begin{array}{l}\text { TTAAACCTCTTCCAGAGT } \\
\text { TCAGCCTTGCGACCATAC }\end{array}$ & 581 & 55 & \\
\hline T. annulata & Tams-1 & $\begin{array}{l}\text { PCR } \\
\text { nPCR }\end{array}$ & $\begin{array}{l}\text { GTAACCTTTAAAAACGT } \\
\text { GTTACGAACATGGGTTT } \\
\text { CACCTCAAAACATACCCC } \\
\text { TGACCCACTTATCGTCC }\end{array}$ & 721 & $\begin{array}{l}55 \\
60\end{array}$ & $\begin{array}{l}\text { Martin-Sanchez } \\
\quad \text { et al. 14] }\end{array}$ \\
\hline T. orientalis & MPSP & PCR & $\begin{array}{l}\text { CTTTGCCTAGGATACTTCCT } \\
\text { ACGGCAAGTGGTGAGAACT }\end{array}$ & 776 & 58 & Ota et al. [16] \\
\hline T. sinensis & MPSP & PCR & $\begin{array}{l}\text { CACTGCTATGTTGTCCAAGAGATATT } \\
\text { AATGCGCCTAAAGATAGTAGAAAAC }\end{array}$ & 887 & 56 & Liu et al. [13] \\
\hline
\end{tabular}

whereas Theileria parva, termed East Coast fever, is primarily distributed in Africa [1]. In these regions where the cattle industry has developed, the economic losses to the industry related to T. annulata are higher than the losses related to Theileria species.

In China, the reported bovine Theileria species mainly include $T$. orientalis, $T$. sinensis, and T. annulata [26], which are widely distributed and constitute a considerable threat. Theileria orientalis is a haemoprotozoan parasite that infects cattle and buffalo, and is typically transmitted by Haemaphysalis ticks [10]. Previous studies have referred to this parasite as $T$. sergenti, $T$. buffeli, or a mixture of T. orientalis, T. buffeli, and T. sergenti; however, T. sergenti has now been replaced by $T$. orientalis. Theileria sinensis exhibits relatively weak pathogenicity, and is primarily distributed throughout Asia (e.g., Japan, China, and the Korean Peninsula) [7]. Theileria sinensis in China was identified in cattle and yak distributed in Gansu and the Qinghai-Tibet Plateau; however, the pathogenicity of the parasite requires further research. Theileria sinensis was first isolated in Gansu, China by Bai et al. from cattle naturally infected with parasites. To determine the taxonomic status of the indeterminate Theileria species, this parasite was compared with other bovine Theileria species by Chinese scholars using morphological comparisons, inoculation tests, and host-specific tests, and was finally termed Theileria sinensis [3]. Theileria annulata is propagated by deadly tick species of the genus Hyalomma, and is widely distributed throughout North Africa, Southern Europe, India, the Middle East, and Central Asia [25]. The life cycle of T. annulata is highly complex, and involves two stages: (1) haploid vegetative propagation in cattle; and (2) diploid sexual reproduction in ticks [5].

Yanbian is located in north-eastern China in the Golden Triangle of north-eastern Asia, and is bordered by North Korea to the south, and Russia to the east. In this study, a total of 584 blood samples of cattle were obtained and tested for the molecular detection of bovine Theileria and species identification.

\section{Materials and methods Ethics}

Farm owners were contacted and permissions were obtained to have their animals involved. All experimental procedures in animals were conducted following the Ethical Principles in Animal Research issued by Yanbian University.

\section{Sample collection and DNA extraction}

In total, 584 cattle blood samples were obtained from the following five counties in Yanbian between 2017 and 2019: Helong (172), Hunchun (157), Longjing (84), Yanji (135), and Dunhua (36). Approximately $10 \mathrm{~mL}$ of blood was aseptically collected from the jugular vein of each animal using vacuum tubes, and stored at $-20{ }^{\circ} \mathrm{C}$ until DNA extraction. The DNA was extracted from the whole blood using a blood extraction kit (OMEGA) and then stored at $-20{ }^{\circ} \mathrm{C}$ until future use.

\section{Primer design and synthesis}

According to the sequences for the Theileria spp. 18S rRNA [4], T. annulata Tams-1 [14], T. orientalis MPSP [16], and $T$. sinensis MPSP [13] genes, six pairs of primers were synthesized by Shanghai Yingjun Biotechnology Co., Ltd. The primer sequences are listed in Table 1.

\section{Bovine Theileria DNA amplification}

Genomic DNA was used as a template for conventional PCR and nested PCR (nPCR) amplification (Table 1). Genomic DNA isolated from cattle infected with $T$. orientalis and distilled water were used as positive and negative controls, respectively. The PCR reaction was conducted in a $20-\mu \mathrm{L}$ reaction mixture comprising $1.0 \mu \mathrm{L}$ of each primer $(10 \mathrm{pmol})$, 4.0 $\mu \mathrm{L}$ template DNA $(50 \mathrm{ng} / \mu \mathrm{L}), 2.0 \mu \mathrm{L}$ dNTP Mix (Baosheng Dalian Bioengineering Co. Ltd), $2.0 \mu \mathrm{L}$ of $10 \times$ Ex Taq buffer, $1 \mu \mathrm{L}$ Ex Taq (Baosheng Dalian Bioengineering Co. Ltd), and $9 \mu \mathrm{L}$ distilled water. The amplification conditions consisted of an initial denaturation step at $95{ }^{\circ} \mathrm{C}$ for $5 \mathrm{~min}$, followed by 30 cycles of denaturation at $94{ }^{\circ} \mathrm{C}$ for $45 \mathrm{~s}$, an annealing step at the temperature set for each primer for $1 \mathrm{~min}$, an extension step at $72{ }^{\circ} \mathrm{C}$ for $1 \mathrm{~min}$, and a final extension at $72{ }^{\circ} \mathrm{C}$ for $7 \mathrm{~min}$. The annealing temperatures are presented in Table 1. 


\section{Sequencing and phylogenetic analysis}

Amplicons from positive PCR products were cloned into the PMD 18T-Simple Vector (Baoshengwu, Dalian, China) and transformed into competent DH5 $\alpha$ cells. Plasmid DNA was extracted using a plasmid extraction kit (OMEGA), and further identified by PCR and double enzyme digestion by restriction endonucleases SaI I and BamH I (Baoshengwu, Dalian, China). The precisely identified products were sent to Shanghai Yingjun Biotechnology Company for sequencing.

The sequences correctly obtained from the present study were subjected to a BLAST analysis using the BLASTn programme in the NCBI GenBank. Multiple alignments and phylogenetic analyses of the obtained sequences of the 18S rRNA and MPSP genes of bovine Theileria were performed using Clustal W [20] (BioEdit version 7.0.9) and the maximum likelihood (ML) (MEGA version 7 software) and Bayesian (MrBayes version 3.2) methods [19]. The substitution model Tamura-3-parameter was used for maximum likelihood (ML) analyses. The search for the ML tree and bootstrap resampling with 1000 replications were performed using MEGA. In the Bayesian analysis, the GTR + G + I model $(n=6$, rates $=$ invgamma $)$ was selected to perform for $10^{6}$ generations with sampling every $10^{3}$ generations and the initial $25 \%$ of the sampled trees were discarded as burn-in. The GenBank accession numbers of the relative species used in this study are shown in Figure 2.

\section{Results}

\section{Molecular prevalence of bovine Theileria}

Primers designed from the Theileria spp., T. annulata, $T$. sinensis, and T. orientalis genes were used for detection of DNA in the 584 bovine blood samples by PCR. The PCR amplification results show that Theileria spp. PCR amplified two fragments consisting of 778 bp (P1, P2) and 581 bp (P3, P4). Theileria sinensis PCR and Theileria orientalis PCR amplified fragments consisting of 887 bp (P5, P6) and 776 bp (P7, P8), respectively. However, all of the blood samples tested negative for T. annulata. The PCR amplification results for Theileria spp., T. sinensis, and T. orientalis are shown in Figure 1A-D.

Among the 584 sampled animals, the prevalence of $T$. sinensis and T. orientalis infection was $27.23 \%$ (159/584) and $26.88 \%$ (157/584), respectively. Additionally T. annulata was not found in our study. The mixed infection rate for $T$. sinensis and T. orientalis was $11.30 \%(66 / 584)$ in this study (Table 2).

\section{Target gene cloning and identification}

The recombined clone plasmids PMD18-T-Theileria spp., PMD18-T-T. sinensis, and PMD18-T-T. orientalis were constructed with positive PCR products and clone vectors. Three gene fragments comprised of $581 \mathrm{bp}, 887 \mathrm{bp}$, and 776 bp were obtained by PCR. Positive clones of each target gene were digested with BamH I and SaI I, and $581 \mathrm{bp}$, 2692 bp, 887 bp, 2692 bp, 776 bp, and 2692 bp fragments were obtained.
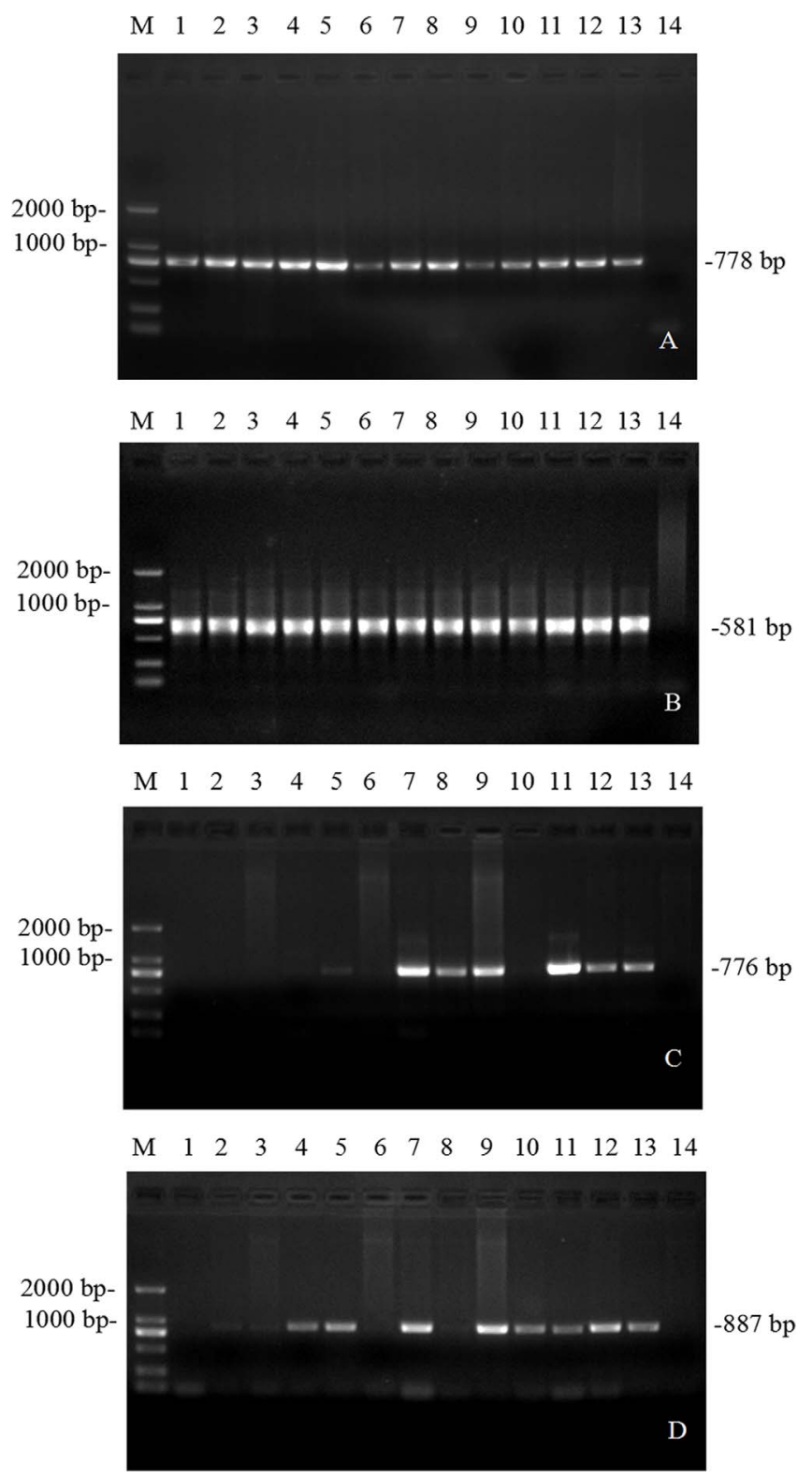

Figure 1. (A) and (B) Theileria spp. nested PCR, M: DL 2000 DNA Marker, lain1: Positive control, lain2-13: Sample products, lain14: Negative control. (C) and (D) T. orientalis PCR and T. sinensis PCR, M: DL 2000 DNA Marker, lain1-13: PCR products of the target gene, lain14: Negative control.

\section{Comparative analysis}

The 18S rRNA gene of Theileria spp., T. orientalis MPSP gene, and $T$. sinensis MPSP gene were identified in this study. Nucleotide sequence identity data demonstrated that the sequence of the 18S rRNA (MN628025) gene shares 100\% sequence identity with China (KX115427.1). The MPSP gene (887 bp) of $T$. sinensis isolated in this study was $100 \%$ identical to a previously published sequence from Jilin (KX375400.1). Similarly, the $T$. orientalis gene obtained in our study had 99.6\% nucleotide homology with Jilin 2 (KY392962.1), and three nucleotide mutations were found. Representative $T$. orientalis and $T$. sinensis MPSP sequences for different 

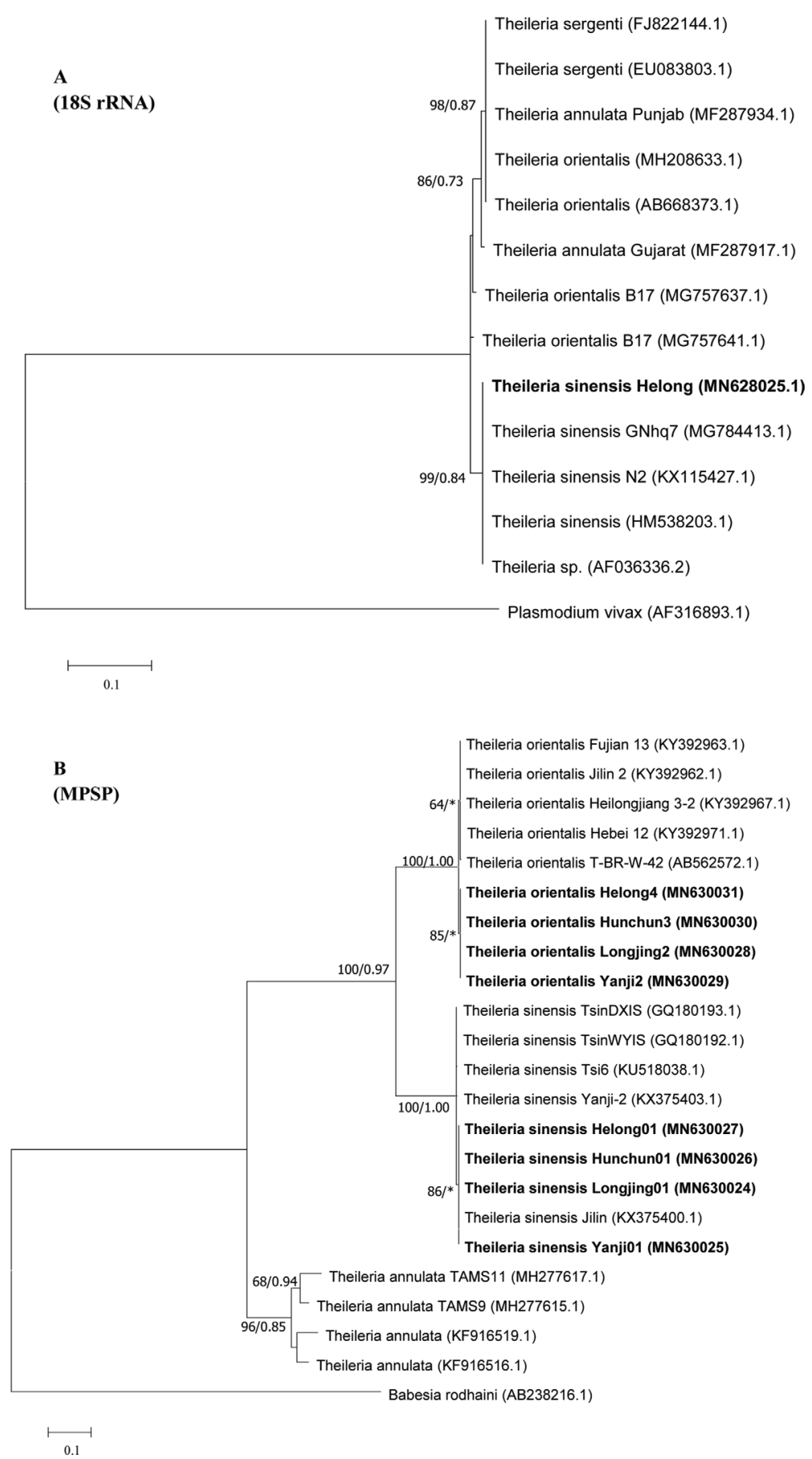

Figure 2. Phylogenetic trees based on the (A) 18SrRNA and (B) MPSP sequences of bovine Theileria. The ML tree was derived from a Tamura 3-parameter model using MEGA7, and Bayesian Inference by Mrbayes3.2 with the GTR + G + I model. ML bootstrap and BI posterior probabilities values are shown at the nodes in the order ML/BI. Bootstrap values $<50$ are not reported. Posterior probabilities $<0.7$ are not reported. The newly generated sequences in the present study are shown in bold.

strains were registered in the GenBank database under accession numbers: MN630024 - MN630031.

\section{Phylogenetic analysis}

Two phylogenetic trees of bovine Theileria were constructed from the 18S rRNA and MPSP gene sequences of our amplicons and those available in GenBank. ML and BI analyses generated phylogenetic trees with similar topologies. A single tree topology was presented with support values (ML/BI). The sequence of the 18S rRNA gene obtained from our study (MN628025) was 100\% identical to that of Guo (MG784413.1) isolated from Haemaphysalis qinghaiensis. The $18 \mathrm{~S}$ rRNA sequence of $T$. sinensis described here formed a well-supported clade with all the studied $T$. sinensis, while the other Theileria species belonged to different clades such as 
Table 2. The single and mixed infection rates of Theileria spp. in cattle in Jilin, China.

\begin{tabular}{|c|c|c|c|c|c|c|c|c|c|c|c|c|}
\hline & \multicolumn{2}{|c|}{$\begin{array}{c}\text { Helong } \\
(n=172)\end{array}$} & \multicolumn{2}{|c|}{$\begin{array}{l}\text { Hunchun } \\
(n=157)\end{array}$} & \multicolumn{2}{|c|}{$\begin{array}{l}\text { Longjing } \\
(n=84)\end{array}$} & \multicolumn{2}{|c|}{$\begin{array}{c}\text { Yanji } \\
(n=135)\end{array}$} & \multicolumn{2}{|c|}{$\begin{array}{l}\text { Dunhua } \\
(n=36)\end{array}$} & \multicolumn{2}{|c|}{$\begin{array}{c}\text { Total } \\
(n=584)\end{array}$} \\
\hline & $\begin{array}{c}\text { No. of } \\
\text { positive }\end{array}$ & $95 \% \mathrm{CI}$ & $\begin{array}{c}\text { No. of } \\
\text { positive }\end{array}$ & $95 \% \mathrm{CI}$ & $\begin{array}{c}\text { No. of } \\
\text { positive }\end{array}$ & $95 \% \mathrm{CI}$ & $\begin{array}{c}\text { No. of } \\
\text { positive }\end{array}$ & $95 \% \mathrm{CI}$ & $\begin{array}{c}\text { No. of } \\
\text { positive }\end{array}$ & $95 \% \mathrm{CI}$ & $\begin{array}{c}\text { No. of } \\
\text { positive }\end{array}$ & $95 \% \mathrm{CI}$ \\
\hline \multicolumn{13}{|l|}{ Single infection } \\
\hline T. sinensis & 42 & $\begin{array}{c}24.42 \\
(18.60- \\
31.35)\end{array}$ & 31 & $\begin{array}{c}19.75 \\
(14.27- \\
26.66)\end{array}$ & 4 & $\begin{array}{c}4.76 \\
(1.87- \\
11.61)\end{array}$ & 16 & $\begin{array}{l}11.85 \\
(7.43- \\
18.39)\end{array}$ & 0 & $0(0-9.64)$ & 93 & $\begin{array}{c}15.92 \\
(13.18- \\
19.11)\end{array}$ \\
\hline T. orientalis & 44 & $\begin{array}{c}25.58 \\
(19.64- \\
32.59)\end{array}$ & 25 & $\begin{array}{c}15.92 \\
(11.02- \\
22.45)\end{array}$ & 8 & $\begin{array}{c}9.52 \\
(4.91- \\
17.68)\end{array}$ & 14 & $\begin{array}{l}10.37 \\
(6.28- \\
16.65)\end{array}$ & 0 & $0(0-9.64)$ & 91 & $\begin{array}{c}15.58 \\
(12.87- \\
18.75)\end{array}$ \\
\hline \multicolumn{13}{|l|}{ Mixed infection } \\
\hline $\begin{array}{l}\text { T. sinensis }+ \\
\text { T. orientalis }\end{array}$ & 28 & $\begin{array}{c}16.28 \\
(11.51- \\
22.52)\end{array}$ & 22 & $\begin{array}{c}14.01 \\
(9.44- \\
20.30)\end{array}$ & 8 & $\begin{array}{c}9.52 \\
(4.91-17.68)\end{array}$ & 8 & $\begin{array}{c}5.93 \\
(3.03- \\
11.26)\end{array}$ & 0 & $0(0-9.64)$ & 66 & $\begin{array}{l}11.30 \\
(8.98- \\
14.13)\end{array}$ \\
\hline Total positive & 114 & $\begin{array}{c}66.28 \\
(58.93- \\
72.92)\end{array}$ & 78 & $\begin{array}{c}49.68 \\
(41.96- \\
57.42)\end{array}$ & 20 & $\begin{array}{c}23.81 \\
(15.98- \\
33.93)\end{array}$ & 38 & $\begin{array}{c}28.15 \\
(21.25- \\
36.26)\end{array}$ & 0 & $0(0-9.64)$ & 250 & $\begin{array}{c}42.81 \\
(38.86- \\
46.86)\end{array}$ \\
\hline $\begin{array}{l}\text { Negative } \\
\text { samples }\end{array}$ & 58 & $\begin{array}{c}33.72 \\
(27.08- \\
41.07)\end{array}$ & 79 & $\begin{array}{c}50.32 \\
(42.58- \\
58.04)\end{array}$ & 64 & $\begin{array}{c}76.19 \\
(66.07- \\
84.02)\end{array}$ & 97 & $\begin{array}{c}71.85 \\
(63.74- \\
78.75)\end{array}$ & 36 & $\begin{array}{c}100 \\
(90.36- \\
100)\end{array}$ & 334 & $\begin{array}{c}57.19 \\
(53.14- \\
61.14)\end{array}$ \\
\hline
\end{tabular}

T. sergenti (Fig. 2A). Concerning the MPSP gene, the phylogenetic analysis showed evidence of three main clades, one consisting of $T$. sinensis and the others $T$. orientalis and T. annulata (Fig. 2B). The phylogenetic analysis indicated that the $T$. orientalis MPSP gene from this study formed one cluster with the isolates from Fujian (KY392963.1), Heilongjiang (KY392967.1), and Thailand (AB562572.1). The isolated T. sinensis formed one clade with Jilin (KX375400.1). In addition, the MPSP genes of the $T$. orientalis isolated in this study were classified near the cluster of $T$. sinensis rather than that of T. annulata.

\section{Discussion}

Theileria orientalis infection occurs most frequently from June to July and September to October, and is the type of bovine theileriosis that spreads most widely throughout China, including in Heilongjiang, Jilin, Hebei, Guangxi, Fujian, Gansu, and Qinghai $[6,11]$. Theileria sinensis was first isolated from Lintao, China, and represents a new species that primarily infects cattle and yak, and is the most common in the middle region of Gansu Province. However, the prevalence of T. sinensis in other regions remains poorly understood [2]. Moreover, T. annulata is widely distributed throughout the world, including in Central Asia, North America, and South Africa. The distribution of this parasite in China mainly includes the desert and semi-desert grasslands in the northwest, as well as North China, Greater Khingan, and the Changbai Mountains in the northeast region. Among these regions, Xinjiang has the highest incidence of $T$. annulata. Bovine theileriosis is closely related to the activity of ticks and is characterised by seasonality and regionality, making it difficult to completely eliminate. Severe disease caused by bovine Theileria in cattle often leads to death, which causes massive economic losses and represents a potential threat for the cattle industry. Yanbian has a long border and is rich in vegetation resources in the eastern mountainous area. Pasture, forest, and barn environments are particularly suitable for tick breeding and reproduction. Therefore, there are various types of ticks in Yanbian including Haemaphysalis longicornis, Dermacentor silvarum, and Ixodes persulcatus, which are the major vectors responsible for transmitting bovine Theileria species.

Our results in Yanbian were that Helong had the highest prevalence of bovine Theileria species, followed by Hunchun, Yanji, and Longjing, whereas Dunhua had 0\% prevalence. The difference in the positive rate of bovine Theileria species among these regions may be directly related to the various feeding conditions of cattle. This is because cattle in extensive grazing conditions have more opportunities to be exposed to vector ticks, which leads to an increased percentage of infection with bovine Theileria. In the present study, blood samples collected from Dunhua were from cattle in captivity, whereas the samples from the other four regions were collected from semi-grazing cattle, which may explain the low prevalence of bovine Theileria species in Dunhua. Furthermore, the Helong region is located in the Eastern Foot of the Changbai Mountains, where there may be an increase in the species and quantity of the ticks. Therefore, the higher prevalence detected in Helong may be closely related to the geographical location [17].

Molecular taxonomic data for bovine Theileria have been relatively absent in China. Since the Theileria spp. gene is a highly effective molecular marker sequence, the genotypes and phylogenetic analysis of these parasites are usually studied by researchers in China and abroad utilizing this gene [8]. The rates of infection found in our study were much higher than those for $T$. sinensis $(17.5 \%), T$. orientalis $(10.9 \%)$, and co-infection with both parasites $(8.8 \%)$ detected by Jia et al. [9]. In addition, $T$. sinensis was found to be primarily distributed in the high altitude regions of China, and is rarely found in the lower elevations of northern China [21]. In a previous study, T. annulata infection was reported in neighbouring 
countries and in southern China [23]; however, no infection was found in this study, which may be related to the distribution of tick species in the sampling areas. Due to the limited sample size and geographical sampling location, $T$. annulata infections were not found in our research, which does not mean that no T. annulata is present in Yanbian. Therefore, further investigation is required to clarify this finding.

Currently, considerable economic losses to the cattle industry have been caused by the widespread distribution of bovine Theileria in China, which also imposes significant constraints on the export of agricultural products [18]. To further understand the epidemic characteristics and regional distribution of bovine Theileria, the specimens collected from five counties in Yanbian were analysed by molecular detection. Moreover, positive specimens were assessed by sequencing and phylogenetic analysis utilising the Theileria spp. 18S rRNA, T. orientalis MPSP, and T. sinensis MPSP genes, which aimed to elucidate the epidemic strains of bovine Theileria species in Yanbian. These results show that $T$. orientalis and $T$. sinensis are two major epidemic strains in this region. The findings of this study provide scientific evidence for the prevalence and geographical distribution of bovine Theileria in the north-eastern frontier of China. This information is useful for the early prevention and control of bovine theileriosis, which can be used to reduce the harm caused by the disease in this region.

\section{Conclusions}

Theileria sinensis $(27.23 \%)$ and T. orientalis (26.88\%) were found in this study. The findings of our study indicated that Yanbian was an epidemic area of bovine theileriosis. Additionally, feeding conditions and the geographical position of farms are two potential risk factors for the prevalence of bovine theileriosis, which is supported by this paper.

\section{Conflict of interest}

The project was supported by the Scientific Research and Innovation Team Project of Yanbian University and Jilin Province, and the Talent Fund Funded Talent Project of Jilin Province. The authors declare that there are no conflicts of interest.

\section{References}

1. Baek BK, Rim BM, Lee WJ, Kim JH, Son DS. 1993. Study on infection of Theileria sergenti in neonatal calves. Korean Journal of Veterinary Research, 3, 665-671.

2. Bai Q, Liu GY, Han GF. 1995. A new indeterminate species of Bovine Theileria found in China. Chinese Journal of Veterinary Science, 01, 16-21.

3. Bai Q, Liu GY, Yin H, Zhao QZ, Liu DK, Ren JX, Li X. 2002. Traditional taxonomic study of a new species 1 of Theileria sinensis sp. nov. Chinese Journal of Animal and Veterinary Sciences, 01, 73-77.

4. Cao S, Zhang S, Jia L, Xue S, Yu L, Kamyingkird K, Moumouni PF, Moussa AA, Zhou M, Zhang Y, Terkawi MA,
Masatani T, Nishikawa Y, Xuan X. 2013. Molecular detection of Theileria species in sheep from northern China. Journal of Veterinary Medical Science, 75(9), 1227-1230.

5. Ding XC, Jiang YP, Sun YM, Tian JH. 1997. The pathological changes of theileriosis sergenti under natural conlitions. Chinese Journal of Veterinary Parasitology, 02, 17-18.

6. Dong Q. 2018. Molecular epidemiological survey of Theileria orientalis and Anaplasma phagocytophilum in parts of Jilin Province. Yanji: Yanbian University.

7. Fujisaki K, Ito Y, Kamio T, Kitaoka S. 1985. The presence of Theileria sergenti in Haemaphysalis longicornis overwintering in pasture in Japan. Annals of Tropical Medicine \& Parasitology, 79(5), 519-524.

8. Goldberg CS, Pilliod DS, Arkle RS, Waits LP. 2011. Molecular detection of vertebrates in stream water: a demonstration using Rocky Mountain tailed frogs and Idaho giant salamanders. PLoS One, 6(7), e22746.

9. Jia LJ, Adjou Moumouni PF, Wang GB, Cao SN, Yu LZ, Jirapattharasate C, Xuan XN, Zhou M, Guo HP, Xue SJ, Liu MM, Gao Y. 2017. Molecular detection of Theileria species in cattle from Jilin province, China. Tropical Biomedicine, 34, $1-9$.

10. Kawazu S, Sugimoto C, Kamio T, Fujisaki K. 1992. Antigenic differences between Japanese Theileria sergenti and other benign Theileria species of cattle from Australia (T. buffeli) and Britain (T. orientalis). Parasitology Research, 78(2), 130-135.

11. Liu J. 2016. Establishment and application of real-time quantitative PCR for the detection of three kinds of Bovine Theileria, Master Dissertation. Lanzhou: Chinese Academy of Agricultural Sciences.

12. Liu AH, Guan GQ, Liu JL, Li YQ, Ma ML, Niu QL, Ren QY, Yin H, Luo JX. 2009. Comparative study on 18S rRNA gene sequence of Bovine Theileria. Chinese Journal of Animal and Veterinary Sciences, 40(07), 1063-1068.

13. Liu A, Guan G, Liu Z, Liu J, Leblanc N, Li Y, Gao J, Ma M, Niu Q, Ren Q, Bai Q, Yin H, Luo J. 2010. Detecting and differentiating Theileria sergenti and Theileria sinensis in cattle and yaks by PCR based on major piroplasm surface protein (MPSP). Experimental Parasitology, 126(4), 476-481.

14. Martin-Sanchez J, Garcia-Fernandez P. 1999. Theileria annulata: genetic characterization of Spanish isolates by isoenzyme electrophoresis and random amplified polymorphic DNA. Experimental Parasitology, 92(1), 57-63.

15. Onuma M, Kakuda T, Sugimoto C. 1998. Theileria parasite infection in East Asia and control of the disease. Comparative Immunology Microbiology \& Infectious Diseases, 21(3), 165.

16. Ota N, Mizuno D, Kuboki N, Igarashi I, Nakamura Y, Yamashina H, Hanzaike T, Fujii K, Onoe S, Hata H, Kondo S, Matsui S, Koga M, Matsumoto K, Inokuma H, Yokoyama N. 2009. Epidemiological survey of Theileria orientalis infection in grazing cattle in the eastern part of Hokkaido, Japan. Journal of Veterinary Medical Science, 71(7), 937-944.

17. Sato M, Kamio T, Tanaka S, Taniguchi T, Fujisaki K. 1994. Development of Theileria sergenti schizonts in the lymph node of experimentally infected cattle. Journal of Veterinary Medical Science, 56(56), 715-722.

18. Shimizu S, Yoshiura N, Mizomoto T, Kondou Y. 1992. Theileria sergenti infection in dairy cattle. Journal of Veterinary Medical Science, 54(2), 375.

19. Sun Z, Jiang C, Feng J, Yang W, Li M, Miao W. 2017. Phylogenomic analysis of Balantidium ctenopharyngodoni (Ciliophora, Litostomatea) based on single-cell transcriptome sequencing. Parasite, 24, 43.

20. Thompson JD, Higgins DG, Gibson TJ. 1994. CLUSTAL W: improving the sensitivity of progressive multiple sequence 
alignment through sequence weighting, position-specific gap penalties and weight matrix choice. Nucleic Acids Research, 22 (22), 4673-4680.

21. Uchida TA, Yanagawa H, Mori T, Shiraishi S. 1985. Ultrastructural observations of the intra-erythrocytic merozoite in Theileria sergenti. Tropical Medicine and Parasitology, 36(1), 35-38.

22. Uilenberg G. 1981. Theilerial species of domestic livestock. Advances in the control of Theileriosis. Netherlands: Springer. p. 4-37.

23. Wooseog J, Hee KC, Jong Man K, Hwan J, Gi PS. 2005. Serological investigation of Theileria sergenti using latex agglutination test in South Korea. Journal of Parasitology, 91(1), 164-169.

24. Xu YT, Zhang SF, Li SY, Jin MH. 1997. The research progress to diagnose and prevent Theileria sergenti. Journal of Agricultural Science Yanbian University, 4, 271-275.

25. Zhai JY, Zhao JZ, Ni YS, Wang SS. 1992. Rapid diagnosis methods to detect cow theileriosis. Chinese Journal of Veterinary Medicine, 6, 30-31.

26. Zhang SF, Xu YT, Song JC, He XJ, Jin SZ. 1997. Studies on Theileriosis sergenti in Hunchun. Journal of Agricultural College of Yanbian University, 01, 52-54.

Cite this article as: Jia L, Zhao S, Xie S, Li H, Wang H \& Zhang S. 2020. Molecular prevalence of Theileria infections in cattle in Yanbian, north-eastern China. Parasite 27, 19.

\section{- PARASTE}

An international open-access, peer-reviewed, online journal publishing high quality papers on all aspects of human and animal parasitology

Reviews, articles and short notes may be submitted. Fields include, but are not limited to: general, medical and veterinary parasitology; morphology, including ultrastructure; parasite systematics, including entomology, acarology, helminthology and protistology, and molecular analyses; molecular biology and biochemistry; immunology of parasitic diseases; host-parasite relationships; ecology and life history of parasites; epidemiology; therapeutics; new diagnostic tools.

All papers in Parasite are published in English. Manuscripts should have a broad interest and must not have been published or submitted elsewhere. No limit is imposed on the length of manuscripts.

Parasite (open-access) continues Parasite (print and online editions, 1994-2012) and Annales de Parasitologie Humaine et Comparée (1923-1993) and is the official journal of the Société Française de Parasitologie. 